
агропродовольственном рынке

\author{
Dolgova S.A. \\ Credit support for agricultural producers in the face of \\ increasing competition in the agro-food market
}

\begin{abstract}
Сезонность сельскохозяйственного производства и связанный с этим характер формирования затрат и запасов обуславливают необходимость предоставления сельскохозяйственным товаропроизводителям заемных средств динамичного развития сельского хозяйства в условиях членства России в ВТО и усиления конкуренции на агропродовольственном рынке можно добиться только при наличии эффективной системы кредитования. В решении этой задачи важнейшая роль принадлежит Россельхозбанку как главному кредитору сельхозтоваропроизводителей
\end{abstract}

Ключевые слова: санкции, ВТО, система кредитования, агропродовольственный рынок

\section{Долгова Светлана Алексеевна}

Кандидат экономических наук, доцент

Российская академия народного хозяйства и

Государственной Службы при Президенте РФ

(Орловский филиал)

2. Орел, Бульвар Победы, 5 A
Seasonality of agricultural production and the related costs and the nature of the formation of reserves necessitate the provision of agricultural producers borrowed funds. The dynamic development of agriculture in terms of Russia's membership in the WTO and the increasing competition in the agro-food market can be achieved only if there is an effective system of credit. In this task, the most important role belongs to the Agricultural Bank as a main agricultural lender

Key words: sanctions, WTO, system of credit, agrifood market

\section{Dolgova Svetlana Alekseevna}

Candidate of Economic Sciences, Associate Professor Russian Presidential academy of national economy and public administration (Orel branch)

Orel, Victory Boulevard, 5 A

Агропродовольственный комплекс России, как и экономика страны в целом, функционирует в весьма сложных и неоднозначных социальноэкономических условиях. На проблемы внутреннего происхождения наложились внешние факторы - санкции и антисанкции. Одновременно идет процесс адаптации к условиям, принятым Россией при вступлении в ВТО, с 2015 года запущен новый интеграционный процесс в рамках Евразийского экономического пространства [1, с.9].

Динамичного развития сельского хозяйства в условиях членства России в ВТО и усиления конкуренции на агропродовольственном рынке можно до- 
биться только при наличии эффективной системы кредитования. Рассматривая кредитование как один из инструментов экономического регулирования развития сельхозтоваропроизводителей следует отметить, что в 2014 году произошло снижение его объемов: совокупный размер выданных кредитов составил 1 трлн руб., что на 13\% меньше, чем в 2013 году [1, с.13].

Снижению объемов кредитования способствовало следующее:

- рост задолженности федерального бюджета по компенсации части затрат на уплату процентной ставки по уже действующим инвестиционным кредитам;

- введение западных санкций, сокращающих доступ российских ведущих банков и финансовых компаний к зарубежным кредитным ресурсам;

- снижением цен на экспортируемую нефть;

- уменьшение доходности значительной части сельскохозяйственных товаропроизводителей.

К началу 2015 года возникла угроза дальнейшего снижения уровня кредитования агропромышленного комплекса, как за счет сокращения его объемов, так и за счет ухудшения условий привлечения заемных средств.

С середины декабря 2014 года ставки по краткосрочным кредитам возросли до 20-22\% годовых, а по инвестиционным до 23-26\%, что превышает средневзвешенный показатель процентной ставки за 2014 год на 10 п. п. [1, c.14].

В сложившихся условиях для сельскохозяйственных организаций серьезной проблемой остается поиск инвесторов для формирования оборотных средств и осуществления капитальных вложений. В решении этой задачи важнейшая роль принадлежит Россельхозбанку как главному кредитору сельхозтоваропроизводителей [2, с.68].

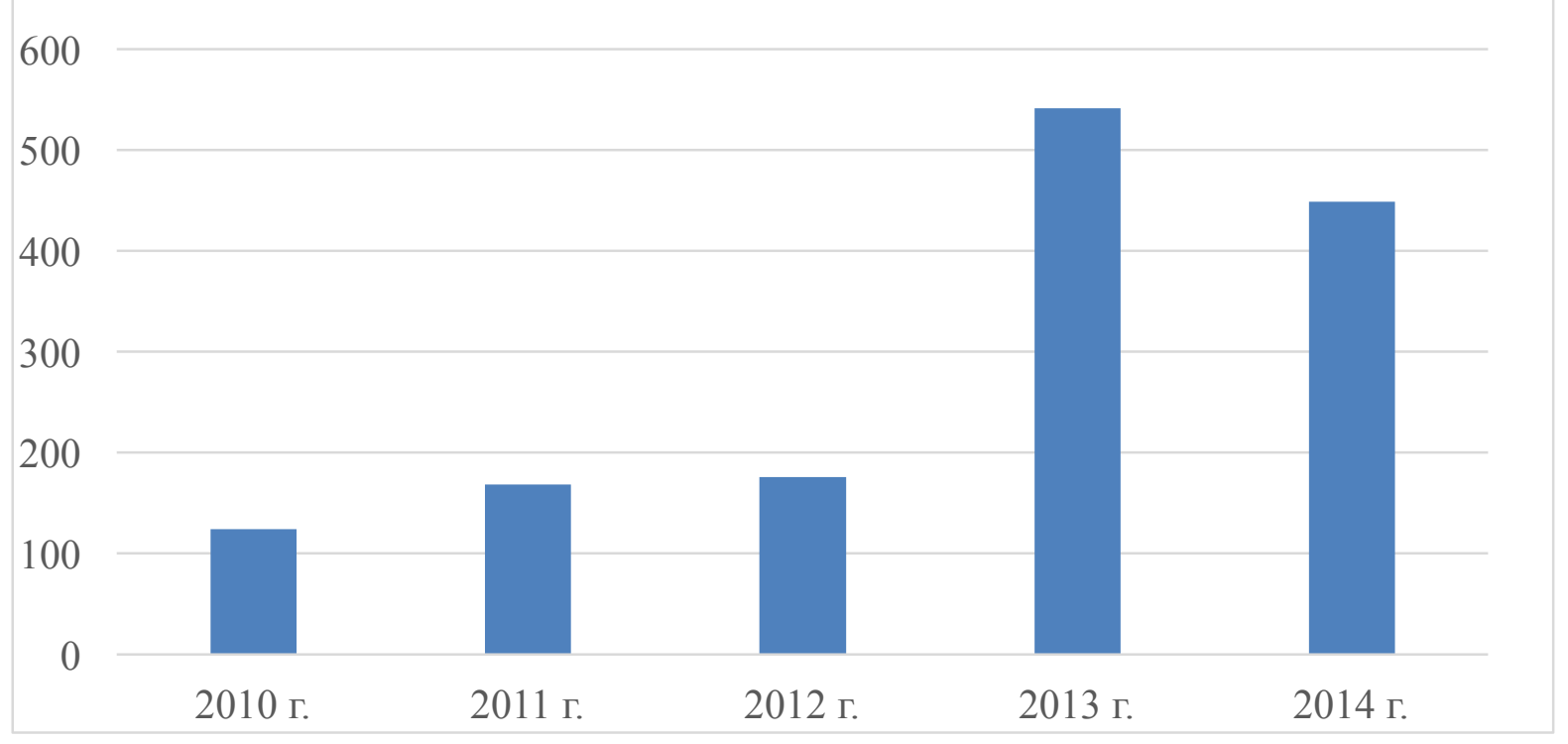

Рис. 1. Динамика количества выданных кредитов АПк 
Основную долю кредитного портфеля Банка традиционно составляют кредиты, предоставленные корпоративным заемщикам. На долю предприятий АПК приходится около $73 \%$ всего объема кредитования, что соответствует Стратегии Банка. За период 2010-2014 гг. было заключено 1,5 млн. кредитных договоров на сумму 2140,1 млрд. руб. (рис. 1).

Одним из направлений кредитования предприятий сельского хозяйства является финансирование сезонных полевых работ, на эти цели за 5 лет было выдано 743,8 млрд. руб. (рис. 2).

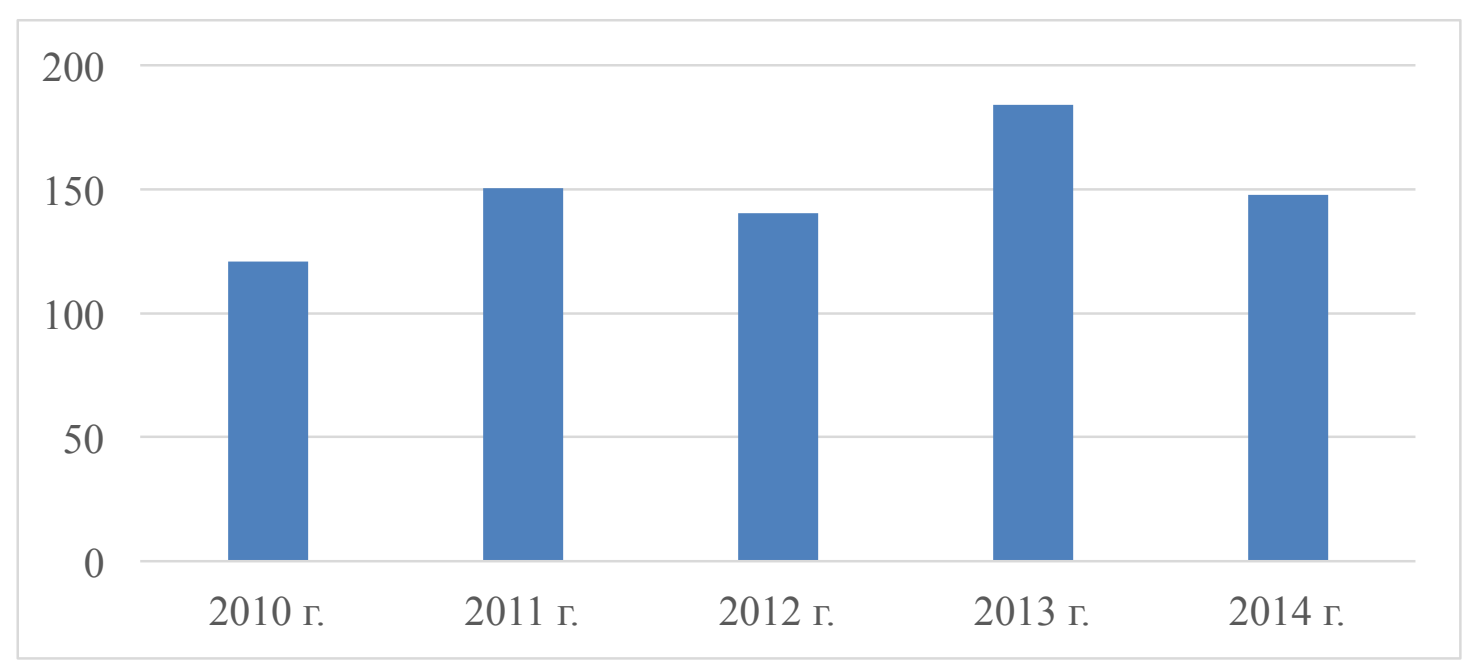

Рис. 2. Динамика объемов кредитования сезонных полевых работ

Поддержка Банком сельхозпроизводителей в целях успешного проведения сезонных полевых работ способствует росту товарного производства и укреплению продовольственной безопасности страны.

Кредиты предприятиям АПК выдавались как на краткосрочные, так и на долгосрочные цели (рис. 3).

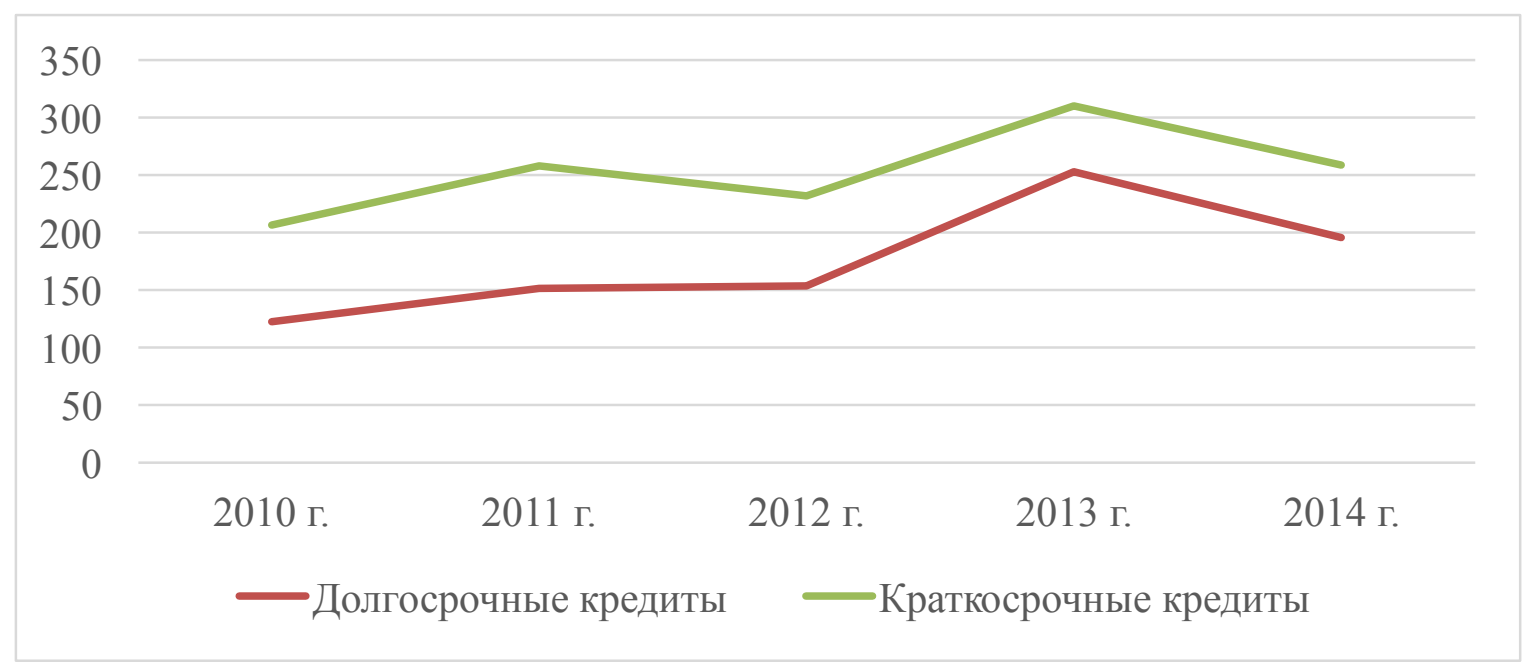

Рис. 3. Динамика кредитов по срокам кредитования 
В структуре кредитного портфеля АПК, доминирующими являются краткосрочные кредиты, на их долю приходилось 60\%. Доля долгосрочных кредитов варьируется с 39,8\% до 43,1\% года.

Сокращение объемов долгосрочного кредитования в 2014 году объясняется недостаточным объемом длинных ресурсов Банка.

\section{Таблица 1. Объемы выданных кредитов АПк по субъектам кредитования млрд. руб.}

\begin{tabular}{|l|c|c|c|c|c|}
\hline Субъекты кредитования & 2010 г. & 2011 г. & 2012 г. & 2013 г. & 2014 г. \\
\hline Предприятия и организации АПК & 285,9 & 341,2 & 317,8 & 427,7 & 340,9 \\
\hline Личные подсобные хозяйства (ЛПХ) & 20,1 & 32,1 & 37,7 & 38,9 & 25,4 \\
\hline $\begin{array}{l}\text { Физические лица, проживающие в сель- } \\
\text { ской местности и населенных пунктах с } \\
\text { численностью населения до 100 тыс. } \\
\text { человек }\end{array}$ & н/д & н/д & н/д & 72,8 & 72,1 \\
\hline $\begin{array}{l}\text { Крестьянские фермерские хозяйства } \\
\text { (КФХ) }\end{array}$ & 18,6 & 30,3 & 27,5 & 21,8 & 14,8 \\
\hline $\begin{array}{l}\text { Сельскохозяйственные производствен- } \\
\text { ные кооперативы, включая кредитные }\end{array}$ & 4,2 & 5,4 & 2,4 & 1,7 & 0,8 \\
\hline Итого выдано кредитов & 328,8 & 409,0 & 385,4 & 562,9 & 454,0 \\
\hline
\end{tabular}

Причиной сложившейся ситуации послужили санкции со стороны ЕС и США, под которые попал Россельхозбанк, а также рост ключевой процентной ставки по кредитам, что ужесточило требования Банка к заемщикам и привело к росту ставки кредитования, а в ряде случаев кредитование отдельных заемщиков было приостановлено полностью.

Учитывая проблему отсутствия залоговой базы у представителей малого бизнеса, Банк предлагает целый ряд беззалоговых кредитов, а также дает возможность воспользоваться гарантиями АО «Федеральная корпорация по развитию малого и среднего предпринимательства» и поручительством одного из 70 региональных гарантийных фондов поддержки малого и среднего предпринимательства.

Важным направлением деятельности Банка в рамках реализации Госпрограммы является финансирование инвестиционных проектов, предусматривающих строительство, реконструкцию и модернизацию объектов АПК (животноводческие комплексы, теплицы, овощехранилища и т.д.) (табл. 2).

\section{Таблица 2. Динамика объемов инвестиционных кредитов АПК}

\begin{tabular}{|l|c|c|c|c|c|}
\hline \multicolumn{1}{|c|}{ Направления кредитования } & 2010 г. & 2011 г. & 2012 г. & 2013 г. & 2014 г. \\
\hline $\begin{array}{l}\text { Строительство, реконструкция и } \\
\text { модернизация объектов АПК }\end{array}$ & 27,7 & 27,6 & 29,5 & 43,4 & 33,4 \\
\hline $\begin{array}{l}\text { Приобретение сельскохозяй- } \\
\text { ственных животных }\end{array}$ & 2,4 & 7,3 & 6,2 & 4,7 & 3,9 \\
\hline $\begin{array}{l}\text { Приобретение сельскохозяй- } \\
\text { ственной техники }\end{array}$ & 23,3 & 42,7 & 38,5 & 28,8 & 21,5 \\
\hline $\begin{array}{l}\text { Выдано инвестиционных креди- } \\
\text { тов }\end{array}$ & 53,4 & 77,6 & 74,2 & 76,9 & 58,8 \\
\hline
\end{tabular}


В целях обеспечения возложенных на Банк Правительством Российской Федерации функций по финансовому оздоровлению сельскохозяйственных товаропроизводителей Банк продолжает реализовывать следующие мероприятия:

- осуществляет мониторинг ситуации по финансовому оздоровлению сельскохозяйственных товаропроизводителей в разрезе регионов и участников программ;

- ежемесячно формирует и направляет в Минсельхоз России сводный отчет об исполнении функций банка-агента по программе финансового оздоровления предприятий сельского хозяйства.

Банк стремится сохранить лидерство в кредитовании предприятий АПК, укрепив позиции в качестве основного инструмента реализации государственных программ, поддержки отрасли сельского хозяйства, как федеральных, так и региональных.

\section{Список используемых источников:}

1. Ушачев И. Аграрный сектор России в условиях международных санкций и эмбарго: вызовы и перспективы // АПК: экономика, управление. 2015. №5. С. 9-22.

2. Хицков А., Чередникова А. Организационно-экономическая оценка системы кредитования сельского хозяйства // АПК: экономика, управление. 2013. №6. С. 68.

(C) 2015, Долгова С.A. Кредитная поддержка сельхозтоваропроизводителей в условиях усиления конкуренции на агропродовольственном рынке
(C) 2015, Dolgova S.A.

Credit support for agricultural producers in the face of increasing competition in the agro-food market 